УДК 94 (477.83) (092): 930.25

DOI 10.24919/2519-058x.4.111459

$10.24919 / 2519-058 \times .4 .111459$

кандидат історичних наук, викладач історії Львівського вищэого професійного училища комп'ютерних технологій та будівництва

(Україна, Львів) olhavladyha@gmail.com

\title{
МИХАЙЛО ГРУШЕВСЬКИЙ ЯК АРХЕОГРАФ (ОГЛЯД ДЖЕРЕЛ)
}

Стаття присвячена джерелознавчому аналізу проблеми «Грушевський-археограф». Запропоновано виокремити три основні джерельні комплекси, визначено опублікований та архівний сегмент кожного $з$ них. Зроблено висновок про достатню інформативність наявних джерел для реконструкиії археографічної спадщини вченого. Окреслено джерельні лакуни проблеми «Грушевський-археограф».

Ключові слова: М. Грушевський, археографія, особові джерела, документи офіційного походження.

Jim. 10.

Olga VLADYHA, PhD (History), Associate Professor of Lviv Professional College of Computer Technologies and Building (Ukraine, Lviv) olhavladyha@gmail.com

\section{MYKHAILO HRUSHEVSKYI AS AN ARCHEOGRAPHER A REVIEW OF THE SOURCES}

The article is devoted to source analysis of the problem «Hrushevskyi as an archeographer». It has been discovered that the archeological heritage of M. Hrushevskyi was the subject of independent analysis in the works of I. Girich, M. Kapral, V. Telvak, V. Pedych, O. Vladyha. Instead, an independent source study analysis of the problem is absent among the scientific works today. The purpose of the paper is to scrutinize sources, the information potential of which allows the reconstruction of the archeological heritage of M. Hrushevskyi. It is proposed to distinguish three main source complexes: 1) a specific text of the historian, which includes the author's works characterizing M. Hrushevskyi as an archaeographer; 2) "great text» - all set of notes written by the pen of the historian; 3) "historical and cultural context» - a collection of materials describing the era and conditions of archeological activity of the scientist. The published and archived segment of each source system is noted. The first set of sources, the most important one, could be split into several types: conceptual archaeological publications; published documentary texts; articles of source nature, fundamental scientific works, informational reports on the activities of archaeological institutions; prefaces to archaeological publications, generalizing historiographic works, reviews and critical materials. Sources of the second and third complexes are classified according to the nature of information (creative, normative and scientific-organizational), content (documentary and narrative), depending on origin (official and personal) and the form of existence (published and archived).It has been emphasized on the special importance of studying the archaeological activity of a historian on the basis of diaries, memoirs and epistolary documents. The conclusion states that available sources are sufficient for the reconstruction of the archaeological heritage of the scientist. The source lacunae of the problem «Hrushevskyi as an archeographer» has been outlined.

Key words: M. Hrushevskyi, archeography, personal sources, documents of official origin.

Ref. 10.

Ольга ВЛАДЫГА,

кандидат исторических наук, преподаватель истории Львовского выстего профессионального училища компьютерных технологий и строительства (Украина, Львов) olhavladyha@gmail.com

\section{МИХАИЛ ГРУШЕВСКИЙ КАК АРХЕОГРАФ (ОБЗОР ИСТОЧНИКОВ)}

Статья посвящена источниковедеческому анализу проблемьл «Грушевский-археограф». Предложено выделить три основные комплексы источников, определен опубликованный и архивный сегмент каждого из 
них. Сделан вывод о достаточной информативности доступных источников для реконструкиии археографического наследия ученого. Определены источниковые лакуны проблемы «Грушевский-археограф».

Ключевые слова: М. Грушевский, археография, личные источники, документы официального происхождения.

Лит. 10.

Постановка проблеми. Минулорічне відзначення 150-ліття від дня народження М. Грушевського актуалізувало проблему вивчення археографічної діяльності видатного вченого як однієї 3 найбільш актуальних для сучасної історіографії складових його спадщини. При цьому увагу було звернуто на потребу розширення узвичаєного кола грушевськознавчих джерел, котрі допомогли б відтворити стереоскопічний портрет Грушевського-археографа. У зв'язку з цим актуальності набуває питання інвентаризації наявних джерел, що уможливлюють реконструювати археографічну спадщину автора «Історії України-Руси».

Аналіз останніх досліджень. Археографічна спадщина М. Грушевського була об'єктом самостійного аналізу в працях I. Гирича [5], М. Капраля [8], В. Тельвака та В. Педича [10, 70-76]. Різноплановим аспектам згаданої проблеми спеціальну увагу присвятила автор цієї статті $[1 ; 2]$. Натомість, самостійний джерелознавчий аналіз проблеми «Грушевський-археограф» на сьогодні відсутній. Цим і зумовлена актуальність нашої розвідки.

Мета статті полягає в інвентаризації джерел, інформаційний потенціал котрих уможливлює реконструювати археографічну спадщину М. Грушевського.

Виклад основного матеріалу. Враховуючи сучасні герменевтичні підходи та методику системно-структурного аналізу, пропонуємо виокремити три основні джерельні комплекси: 1) конкретний текст історика, який включає авторські твори, що характеризують М. Грушевського як археографа; 2) «великий текст» - вся сукупність пам’яток, що вийшли 3-під пера історика; 3) «історико-культурний контекст» - сукупність матеріалів, що характеризують епоху та умови наукової діяльності вченого [9, 37-38]. Такий поділ видається нам виправданим, оскільки дає змогу охопити весь комплекс необхідних для дослідження джерел. Згадана класифікація особливо виправдана при вивченні історіографічної і, спеціально, археографічної спадщини М. Грушевського. Як слушно зауважила Г. Сварник, джерельно-документальна база грушевськознавства «загалом, неоднорідна і включає великий діапазон джерел різних рівнів» [9, 235-236].

Перший комплекс джерел - найважливіший, він розпадається на кілька видів: концептуальні археографічні публікації; опублікований документальний матеріал; статті джерелознавчого характеру, видані насамперед у «Записках НТШ», «Записках УНТ» та «Україні»; фундаментальні наукові праці («Історія України-Руси», «Історія української літератури»); інформаційні повідомлення про діяльність археографічних установ; передмови до археографічних видань, узагальнюючі історіографічні праці, рецензії та критичні матеріали й ін.

3 огляду на подальший поступ української археографії надзвичайне значення мають концептуальні археографічні публікації, в яких М. Грушевський діагностував актуальний стан і визначав найбільш важливі напрями поступу в сфері віднайдення, опрацювання та видання джерельного матеріалу. Тут передовсім слід згадати про записку до Виділу НТШ («Про виданє джерел до істориї українсько-руської»), яку професор запропонував ще восени 1894 р. Саме цей, новаторський для тогочасної історіографії документ, визначив провідні напрями діяльності утвореної Археографічної комісії НТШ. Не менш важливим є й інший документ - «Записка предложена археографічній комісії проф. Грушевським в справі видання корпусу матеріалів до історії козаччини» (1905). Згідно із задумом автора «Записки», НТШ мало переакцентувати свої археографічні пріоритети у напрямі видання джерел до історії козаччини. Саме це завдання видатний історик визначив як найбільш важливе для тогочасної україністики.

Подібні концептуальні археографічні пропозиції М. Грушевський висловлював і в радянський період свого життя, коли керував Археографічною комісією ВУАН. Протоколи останньої, котрі відклалися в Інституті Рукопису НБУ ім. В. Вернадського, доносять до нас декілька цікавих, до цього часу неопублікованих виступів академіка. Так, на першому ж засіданні АК ВУАН, коли М. Грушевського було обрано головою, він виклав власне бачення стану української археографії 
та запропонував план реалізації найбільш важливих проектів. Згідно із цим планом й працювала київська академічна комісія.

Ще один цікавий неопублікований документ, вартий особливої уваги, стосується плану реорганізації архівної мережі в радянській Україні, який М. Грушевський разом з іншими членами комісії запропонував для обговорення з'їду архівних працівників. Поза сумнівом, віднайдені в архіві АК ВУАН документи варті публікації з огляду на висловлені в них пропозиції, що мають не лише історіографічну вартість, але й можуть стати у нагоді нашим сучасникам.

Не менш важливими є джерельні публікації М. Грушевського. Тут насамперед слід згадати публікаторську працю вченого у заснованій ним серії «Жерела до історії України-Руси». 3 дев’яти томів, котрі з'явилися протягом 1894 - 1913 рр., голова НТШ особисто упорядкував і видав чотири томи люстрацій. Цінність цього виду джерел, попри зрозумілу джерельну вартість, полягає в можливості реконструювати методику археографічної праці М. Грушевського, з'ясувати традиційне і новаційне в його публікаторській техніці.

Менші джерельні публікації, котрі тематично чи хронологічно не відповідали концепції серійних археографічних видань, М. Грушевський оперативно публікував на шпальтах редагованої ним історичної періодики («Записки НТШ», «Записки УНТ» та «Україна»). Відзначимо, що на сторінках цих видань 3'явилася друком найбільш численна складова публікаторської спадщини історика. Цінність джерельних статей також полягає в можливості реконструкції археографічних принципів і публікаторської методики М. Грушевського, розуміння не тільки його власних тематичних зацікавлень на тому чи тому відтинку життєвого шляху, але й загальних потреб україністики того часу. Цікаво, що у львівський період М. Грушевський нерідко практикував свої джерелознавчі статті, що вийшли друком на сторінках «Записок НТШ», видавати окремими збірками під загальною назвою «Матеріали до історії суспільно-політичних і економічних відносин Західної України».

Дослідники археографічної спадщини М. Грушевського не завжди відповідним чином оцінюють евристичну значущість узагальнювальних праць ученого, насамперед - «Історії України-Руси» та «Історії української літератури». Зосереджуючись на спеціальних джерелознавчих студіях ученого, україністика XX ст. цілком незаслужено ігнорує його багатотомники. Натомість на сторінках цих праць натрапляємо першодруки джерел - не лише у фрагментах, але й нерідко повнотекстові варіанти. При цьому можемо простежити певну тенденцію - від тому до тому кількість друкованих джерел у фундаментальних студіях М. Грушевського постійно зростає. Особливо це стосується «Історії України-Руси», на сторінках останніх томів якої ми нерідко зустрічаємо коментовані тексти джерел, а також розлогі джерельні додатки.

Значну інформаційну цінність несуть різнопланові повідомлення М. Грушевського про діяльність археографічних установ. Ця інформація з'являлася, як правило, у відділах хроніки «Записок НТШ», «Записок УНТ» та «України». Після започаткування «Хроніки НТШ», головний обсяг інформації про археографічні плани Товариства, нерідко й авторства М. Грушевського, з'являвся на її сторінках. Вказані повідомлення для сучасного дослідника є надзвичайно цінними, оскільки містять оперативну інформацію про археографічні плани та перебіг їх реалізації, висвітлюють проблеми в цьому напрямі та бачення М. Грушевським шляхів їх подолання. Ця інформація дозволяє нам також осягнути археографічні пріоритети видатного історика, його сприйняття успіхів та невдач у галузі пошуку та публікації джерел. Частина таких інформаційних повідомлень, передусім радянського десятиліття, не була опублікована і міститься у протоколах засідань АК ВУАН.

Значну цікавість для дослідника мають різноманітні передмови та вступи М. Грушевського до археографічних видань. Інформаційну вартість цього виду документів для дослідника археографічної спадщини вченого також неможливо переоцінити. В названих передмовах як до власних документальних видань, так і до джерельних збірок своїх учнів, видатний історик відкриває перед читачем незнані мотиви появи того чи того документального комплексу, особливостей його копіювання, опрацювання й видання, врешті - значення виданих документів для української історіографії. Зазначимо, що нерідко саме передмови М. Грушевського є єдиним джерелом інформації для нас про приховані від загалу нюанси археографічної діяльності як його самого, так і 
співробітників. Наприклад, у передмові до видання творів I. Джиджори вчений привідкрив завісу над численними проблемами функціонування АК НТШ [6, III-VIII].

Потужне рефлективне значення мають історіографічні праці М. Грушевського, в яких наводиться оцінка минулого та актуального стану української археографії. Численні нариси, котрі він присвятив осмисленню стану історичної науки, містять його бачення ролі археографії для модернізації гуманітаристики. Тут слід згадати розлогі нариси М. Грушевського, присвячені НТШ, УНТ, ВУАН та загалом українській науці першої третини ХХ ст.

Характеризуючи джерельну базу археографічної грушевськіани, ми хотіли б звернути увагу на рецензії. Очевидне їх недооцінювання, на нашу думку, послаблює доказовість спостережень стосовно археографічної спадщини М. Грушевського. Адже саме в рецензіях, стисло та лаконічно, обговорюються численні методичні та практичні проблеми археографічних пошуків. В критичних оглядах історик нерідко акцентував важливі для нього моменти археографічної праці. Особливо багато побажань до археографів, як про це свідчать рецензії вченого, стосувалося культури оформлення наукового апарату книги.

Джерела другого комплексу класифікуються за характером інформації (творчі, нормативно-законодавчі та науково-організаційні), змістом (документальні й наративні), походженням (офіційні й особисті) та формою існування (опубліковані й архівні). Серед них важливе місце посідають документальні матеріали. Це насамперед - численні автобіографії вченого. Цей вид джерел містить певну інформацію про бачення вченим подій свого життя та творчості, в тому числі й особливостей археографічної праці. Наприклад, лише в «Автобіографіях» ученого відбито його розуміння важливості виховання нових кадрів українських археографів. Також цей вид джерел несе нам рефлексії видатного історика стосовно його власних археографічних пошуків.

Сучасна «нова біографічна» чи «персональна» історія все більше тяжіє до техніки мікроаналізу, що зумовлює також певну специфіку при ієрархізації джерел. У зв’язку із цим особлива увага надається аналізу персональних текстів, в яких виявляється зафіксованим індивідуальний досвід, а також той чи той рівень його осягнення. Відтак великий інтерес для нас становлять щоденникові джерела. Видання щоденників М. Грушевського вплинуло на всі напрями грушевськознавчих пошуків, в тому числі на вивчення його археографічної спадщини. Щоденники вченого львівської доби, видані І. Гиричем та О. Тодійчук [7], увели нас до творчої лабораторії дослідника, пролили світло на його архівну працю, невідрефлектоване бачення успіхів та труднощів археографічної роботи, врешті - оцінок джерелознавчого пошуку учнів і співробітників. Завдяки щоденникам, можемо простежити контакти вченого в середовищі архівістів, з'ясувати ступінь впливовості оточення на археографічну активність історика. Незважаючи на видання щоденників М. Грушевського в останні десятиліття, і в цій галузі наявні значні пошуково-видавничі перспективи.

Найчисленнішим видом другого комплексу джерел є епістолярна спадщина М. Грушевського. Так, тільки в ЦДІАК зберігається близько тисячі його листів [4, 8-97]. Значні «поклади» листів $\epsilon$ в інших архівосховищах України та сусідніх країн. Епістолярій М. Грушевського - унікальне першоджерело для реконструкції і дослідження його доби. Водночас листи історика - це інтегральна частина його творчості, що доповнює автобіографічні та інші матеріали. Для реконструкції археографічної праці М. Грушевського вагу епістолярних джерел неможливо переоцінити. Так, винятково з листів ми дізнаємося про перебіг археографічних експедицій. У цьому випадку вони виступають фактично звітами учнів і співробітників ученого, котрі реалізовували плани львівської та київської археографічних комісій. 3 листів ми також отримуємо унікальну інформацію про фінансові та організаційні особливості археографічної праці М. Грушевського та його колег. Врешті, листи дають нам можливість з'ясувати непублічне ставлення історика до багатьох аспектів археографічного процесу. Для прикладу, згадаємо листи М. Грушевського до I. Франка, у яких вчені обговорюють методику видання історичних джерел. Відзначимо, що до нашого часу видано значну, проте далеко не повну частину епістолярію М. Грушевського.

Не менш важливим $є$ і третій джерельний комплекс, використання джерел якого дозволяє реконструювати інтелектуальну атмосферу тієї доби, повніше відновити контекст археографічної творчості історика, виявити можливі впливи на процес формування його поглядів та їх обговорення сучасниками. Саме цей комплекс дає змогу об'єднати в межах однієї системної джерельної 
сукупності документи архівних фондів низки установ. Джерела цього комплексу класифікуються за аналогією до попереднього.

Важливе місце в третьому комплексі джерел посідають документальні матеріали. Це - документація установ археографічного характеру, з якими співпрацював чи ними керував М. Грушевський. Тут передовсім маються на увазі протоколи засідань львівської та київської археографічних комісій, на яких ініціювалися та обговорювалися видавничі плани. Відзначимо, що протоколи АК НТШ доволі повно відображені в «Хроніці НТШ». Протоколи АК ВУАН не друкувалися і зберігаються в Інституті Рукопису НБУ ім. В. Вернадського.

Також важливе значення для реконструкції організації М. Грушевським археографічної праці мають протоколи засідань Історично-філософічної секції НТШ, Ради УНТ в Києві, Історично-філологічного відділу ВУАН. Ці документи дають змогу з'ясувати обговорення запропонованих ученим археографічних планів на вищому адміністративному рівні та відтворити дискусії довкола пропозицій історика. Ці джерельні комплекси також очікують оприлюднення.

Серед документації, очолюваних М. Грушевським археографічних комісій, що зберігаються у львівських та київських архівах, значну цінність мають численні звіти членів комісій та самого голови про пророблену роботу за певні періоди, заяви про археографічні відрядження, спроби нарисів діяльності археографічних установ тощо. Ці документи значно збагачують наше розуміння «буденності» археографічної праці М. Грушевського, особливостей його взаємин з колегами, висвітлюють бюрократичні нюанси археографічної праці, що були особливо відчутні в радянський період життя вченого.

Епістолярій - найчисленніший вид і цього джерельного комплексу. Так, тільки в ЦДІАК, за підрахунками I. Гирича, зберігається понад 13 тисяч листів до М. Грушевського від різних осіб, установ та організацій [4, 8-97]. Значні масиви листів кореспондентів М. Грушевського зберігаються в інших архівосховищах України та сусідніх країн. Велику кількість епістолярних джерел видано за роки незалежності. Про важливість епістолярію влучно висловився І. Гирич: «Листи до історика - почасти єдине джерело інформації про події історичної давнини, про процес роблення політичних програм, заміри, інтелектуальні суперечки, взаємини між визначним діячами цієї доби» $[3,1]$.

Висновки. У підсумку маємо зауважити, що виявлена евристичним шляхом сукупність джерел історіографічного характеру, попри деякі прогалини, є, загалом, достатньо репрезентативною для реконструкції археографічної діяльності М. Грушевського. Водночас маємо відзначити також існування певних джерельних «резервів». Наприклад, досі невиданими залишається більшість епістолярію вченого та його співробітників, справочинство НТШ, УНТ та ВУАН. Залишаються питання й щодо можливостей пошуку досі не виявленої грушевськіани, про що свідчать численні публікації, присвячені цій проблемі.

\section{СПИСОК ВИКОРИСТАНИХ ДЖЕРЕЛ І ЛІТЕРАТУРИ}

1. Владига О. Діяльність Михайла Грушевського на чолі Археографічної комісії ВУАН / Ольга Владига // Spheres of culture. - Lublin, 2012. - Volume I. - S. 256-265.

2. Владига О. М. Михайло Грушевський - голова Археографічної комісії НТШ / Ольга Владига // Дрогобицький краєзнавчий збірник. - Вип. XVI. - Дрогобич: Коло, 2012. - С. 283-294.

3. Гирич I. Архів М. Грушевського як джерело для вивчення діяльності визначних постатей українського руху (М. Грушевський, С. Єфремов, В. Липинський, М. Василенко) / Ігор Гирич / автореф. дис. ... канд. істор. наук. - К., 1995. - 24 с.

4. Гирич І. Упорядник. Епістолярна спадщина Михайла Грушевського. Покажчик до фонду № 1235 у ЦДІА України у м. Києві. - К., 1996. - 107 с.

5. Гирич І. Б. Організація М. С. Грушевським археографічної роботи у львівський період життя й діяльності (1894 - 1914 рр.) / І. Б. Гирич // Український історичний журнал. - 1997. - № 1. - С. $72-86$.

6. Грушевський М. Передмова / Михайло Грушевський // Джиджора I. Україна в першій половині XVII віку: Розвідки і замітки. - К., 1930. - С. III - VIII.

7. Грушевський М. Щоденник / Михайло Грушевський / Підг. до друку І. Гирич та О. Тодійчук // Український історик. - 2006 - 2007. - № 4 / 1 - 2. - С. 15-74.

8. Капраль М. Археографічна комісія Наукового товариства ім. Шевченка у Львові. (Нарис історії діяльності) / Мирон Капраль // Український археографічний щорічник. - Випуск 3 - 4. - К., 1999. - С. 56-76. 
9. Сварник Г. Джерелознавча база грушевськознавства / Галина Сварник // Михайло Грушевський $\mathrm{i}$ Львівська історична школа. Матеріали конференції. - Львів-Нью-Йорк, 1995. - С. 233-237.

10. Тельвак В. Львівська історична школа Михайла Грушевського / Віталій Тельвак, Василь Педич. Львів: Світ, 2016. - 440 с.

\section{REFERENCES}

1. Vladyha O. Diyal'nist' Mykhayla Hrushevs'koho na choli Arkheohrafichnoyi komisiyi VUAN / Ol'ha Vladyha // Spheres of culture. - Lublin, 2012. - Volume I. - S. 256-265.

2. Vladyha O.M. Mykhaylo Hrushevs'kyy - holova Arkheohrafichnoyi komisiyi NTSh / Ol'ha Vladyha // Drohobyts'kyy krayeznavchyy zbirnyk. - Vyp. XVI. - Drohobych: Kolo, 2012. - S. 283-294.

3. Hyrych I. Arkhiv M.Hrushevs'koho yak dzherelo dlya vyvchennya diyal'nosti vyznachnykh postatey ukrayins'koho rukhu (M. Hrushevs'kyy, S. Yefremov, V. Lypyns'kyy, M. Vasylenko) / Ihor Hyrych / Avtoref. dys. ... kand. istor. nauk. - K., 1995. - 24 s.

4. Hyrych I. Uporyadnyk. Epistolyarna spadshchyna Mykhayla Hrushevs'koho. Pokazhchyk do fondu № 1235 u TsDIA Ukrayiny u m. Kyyevi. - K., 1996. - 107 s.

5. Hyrych I. B. Orhanizatsiya M. S. Hrushevs'kym arkheohrafichnoyi roboty u l'vivs'kyy period zhyttya y diyal'nosti (1894 - 1914 rr.) / I. B. Hyrych // Ukrayins'kyy istorychnyy zhurnal. - 1997. - № 1. - S. 72-86.

6. Hrushevs'kyy M. Peredmova / Mykhaylo Hrushevs'kyy // Dzhydzhora I. Ukrayina v pershiy polovyni XVII viku: Rozvidky i zamitky. - K., 1930. - S. III-VIII.

7. Hrushevs'kyy M. Shchodennyk / Mykhaylo Hrushevs'kyy / Pidh. do druku I. Hyrych ta O. Todiychuk // Ukrainskyi istoryk. - 2006 - 2007. - № 4 / 1-2. - S. 15-74.

8. Kapral' M. Arkheohrafichna komisiya Naukovoho tovarystva im. Shevchenka u L'vovi. (Narys istoriyi diyal'nosti) / Myron Kapral' // Ukrayins'kyy arkheohrafichnyy shchorichnyk. - Vypusk 3-4. - K., 1999. - S. 56-76.

9. Svarnyk H. Dzhereloznavcha baza hrushevs'koznavstva / Halyna Svarnyk // Mykhaylo Hrushevs'kyy i L'vivs'ka istorychna shkola. Materialy konferentsiyi. - L'viv-N'yu-York, 1995. - S. 233-237.

10. Tel'vak V. L'vivs'ka istorychna shkola Mykhayla Hrushevs'koho / Vitaliy Tel'vak, Vasyl' Pedych. - L'viv: Svit, 2016. - $440 \mathrm{~s}$.

Стаття надійшла до редакизї 15.08.2017 p. 